\title{
Grundtvig-Selskabet af 8. september 1947: Årsberetning 2006
}

\author{
Af Peter Balslev-Clausen
}

Grundtvig-Selskabets årsmøde 2005 blev afholdt lørdag den 29. oktober 2005 på Engelsholm Folkehøjskole i forbindelse med Grundtvig-Selskabets todages seminar om "Højskolen i vadestedet ..."

Ved årsmødet, der blev afviklet med provst Finn Riber Jensen som dirigent, blev K. E. Bugge og Theodor Jørgensen genvalgt og Erik Kelstrup, Henrik Wigh-Poulsen, Ove Korsgaard, Sune Auken og Regner Birkelund valgt til styrelsen. Til forretningsudvalget blev Erik Jakob Petersen og Jens Holger Schjørring genvalgt. Forretningsudvalget konstituerede sig derefter med Peter Balslev-Clausen som formand, Flemming Lundgreen-Nielsen som næstformand, Erik Jakob Petersen som kasserer, Kim Arne Pedersen som sekretær, Jens Holger Schjørring, Flemming Lundgreen-Nielsen, Kim Arne Pedersen, og S. A. J. Bradley i redaktionen for Grundtvig-Studier (med Jens Holger Schjørring som ansvarshavende redaktør) og Christian Thodberg som menigt medlem.

Det seminar, der blev afholdt i forbindelse med årsmødet, var blevet planlagt af Erik Jakob Petersen og Kim Arne Pedersen i samarbejde med højskoleforstander Jesper Vognsgaard. Ud fra seminarets tema, Grundtvigsk livsoplysning, blev der givet oplæg af Britta Schall Holberg og Hans Jørgen Vodsgaard ("Grundtvigsk livsoplysning folkelighed og dannelse"), Ove Korsgaard og Harry Haue ("Grundtvigsk livsoplysning og faglighed"), Kristian Kjær Nielsen og Jens Dolin ("Grundtvigsk livsoplysning og videnskab") og Sune Auken og Laust Riis-Søndergaard ("Grundtvigsk livsoplysning dannelse, forståelse og grundtvigsk kultur”). Der udspandt sig en livlig diskussion, og der var almindelig enighed om, at der burde afholdes et lignende seminar i forbindelse med næste årsmøde. Forskellige forhold har betydet, at dette ikke har kunnet lade sig gøre, og at årsmødet $\mathrm{i}$ stedet bliver afholdt i København, i Vartov, hvilket dog ikke betyder, at tanken om at afholde et seminar i forbindelse med årsmødet er opgivet.

Forretningsmødet har siden sidste årsmøde holdt et kombineret konstitutions- og planlægningsmøde den 14. november 2005 i Vartov, hvor blandt andet de ændringer i selskabets vedtægter, der er til afstemning på dette årsmøde, blev drøftet. Allerede den 19. november (2005) afholdt forretningsudvalget et planlægningsmøde på Center for 
Grundtvigstudier ved Aarhus Universitet. Her blev blandt andet Grundtvig-Selskabets arbejde i nordisk perspektiv drøftet.

Siden Grundtvig-Selskabets sidste årsmøde har selskabets norske afdeling fået ny formand, idet afdelingens hidtidige formand, sognepræst Kirsti Aasen er blevet afløst af sognepræst, dr.theol. Synnøve Sakura Heggem. Kirsti Aasen har været formand for den norske afdeling af selskabet siden dens oprettelse 1982. Det er i høj grad hendes initiativ, hendes udfarende og vedholdende kraft, der har formet og konsolideret den norske afdeling. $\mathrm{Nu}$ ved det norske formandsskifte ser vi i Danmark frem til et frugtbart samarbejde med afdelingens nye ledelse. Den 20. maj afholdt den norske afdeling et "Seminar om Grundtvig og det danske i det nynorske". Efter en indledende, med Grundtvig i tekst og toner, koncert ved førsteamanuensis Sigvald Tveit, talte professor Erik A. Nielsen ("Grundtvigs salmedigtning"), folkehøjskolestyrer Arild Mikkelsen ("Grundtvig og det danske i det nynorske"), sognepræst Synnøve Heggem ("Bruderetorikken i nokra utvalde Grundtvig-salmar"), bibeloversætter Anders Aschim ("Blix og Grundtvig") og biskop Jan Lindhardt ("Hvornår er en salme en salme?"). Seminaret blev afsluttet af en diskussion, ledet af professor Bjørn Kvalsvik Nicolaysen). Se også s. 278.

Center for Grundtvigstudier ved Aarhus Universitet, der ledes af Jens Holger Schjørring, og som faste medarbejdere har Anja Stokholm [pr. 1. februar 2006 afløst af Ulrik Overgaard] og Anne-Grethe Jørgensen Dion, har fortsat S. A. J. Bradley tilknyttet i forbindelse med det engelske Grundtvig-oversættelsesprojekt, ligesom Christian Thodberg, Jette Holm og Elisabeth A. Glenthøj fortsat arbejder med udgivelsen af Grundtvigs Vartov-prædikener. [Dette prædikenprojekt er afsluttet pr. 1. februar 2007, og prædikenerne udkommet]. De to ph.d.-studerende Anders Holm og Ulrik Overgaard arbejder fortsat med deres Grundtvig-projekter, henholdsvis "Samtidsproblemet hos Grundtvig og Kierkegaard" [afsluttet med ph.d. forsvar den 31. august 2007] og "Den grundtvig-koldske grundskolepædagogik" i dens relation til kristen livsforståelse, ligesom Uffe Jonas arbejder med projektet "Kvindeevangeliet - Om Grundtvigs mandebilleder og kvindesyn".

Det århusianske Center for Grundtvigstudiers samarbejdspartner i København, Grundtvig-Akademiet i Vartov, har i vintersæsonen 200506 gennemført en foredragsrække under overskriften "Alle mine kilder" sammen med Søren Kierkegaard Forskningscenteret, der nu også har til huse i Vartov. 12 kendte personligheder fra det offentlige liv, politikere og mediefolk, har fortalt om, hvordan Grundtvig og Kierkegaard har påvirket dem. Efteråret 2006 har GrundtvigAkademiet sammen med Det Teologiske Fakultet ved Københavns 
Universitet under åbent universitet gennemført en forelæsningsrække om Grundtvigs teologi. Efter en indledningsforelæsning ved Henrik Wigh-Poulsen fulgte forelæsninger af Svend Bjerg ("Troens erfaring"), Theodor Jørgensen ("Troens vækst"), Hans Raun Iversen ("Kirkeforståelse - livsord og livstegn"), Jens Holger Schjørring ("Grundtvig og kristenheden"), Ulrik Overgaard ("Kirke og skole - og forholdet mellem tro og anskuelse"), Peter Balslev-Clausen ("Salmerne som kommunikation"), Sune Auken ("Vekselvirkningen mellem myte, historie og kristendom, og Forkyndelsen og det poetiske sprog") og Niels Henrik Gregersen ("Grundtvigs trinitariske nådesteologi").

Ved siden af Grundtvig-Akademiet er Grundtvig-Biblioteket under bibliotekar Liselotte Larsens ledelse en vigtig faktor i det videnskabelige - og folkelige - miljø omkring Grundtvig-forskningen i Vartov, og København, side om side med Vartov-Arkivet for Grundtvigs pædagogiske virkningshistorie under Morten Mortensens ledelse.

Igen $\mathrm{i}$ år samler Grundtvig-selskabets årbog, Grundtvig-Studier, under Jens Holger Schjørring, S. A. J. Bradley, Flemming LundgreenNielsen og Kim Arne Pedersens redaktion, en bred vifte af artikler, der dækker den forskningsmæssige indsats vedrørende Grundtvig og hans virkningshistorie. Årbogen indeholder i år bidrag fra Ulrik Overgaard (“"Til Asylernes Venner og Veninder': Kommenteret tekstudgivelse om Grundtvigs kamp for asylskolernes frihed"), Aage Schiøler ("Det hele menneske og en kristologisk funderet forsynstanke: Om brugen af 'Sjæl' og 'Støv' i to grundtvigsalmer"), K. E. Bugge ("En upåagtet dimension i Grundtvigs tanker om 'Anskuelsen"'), Inge Adriansen ("Grundtvigs bidrag til udvikling af danske nationale symboler"), Christian Adamsen ("Antikvarer og oldforskning på Grundtvigs tid"), S. A. J. Bradley ("Grundtvig, Bede and the testimony of antiquity"), Vagn Wåhlin ("Popular, religious and social movements: Recent research approaches and qualitative interpretations of a complex of historical problems"), Henning Eichberg ("The physical culture academy: People's education through sport in Denmark"), Ove Korsgaard ("Debatforum: Hvordan erindres folkehøjskolens historie?"; se dog kommentar s. 236), Kim Arne Pedersen ("Debatforum: Dannelsesbegrebet som element i folkehøjskolens selvforståelse"), Anja Stokholm ("Debatforum: Forkyndelse og formidling - i Grundtvigs prædikener og i dag"), Aage Jørgensen ("Grundtvig-litteratur 2001-2005: en bibliografi”) og Harry Aronson (“Boganmeldelse: Grundtvig - nyckeln till det danska?").

I oktober 2006 udkom 18. udgave af Højskolesangbogen, udgivet af Folkehøjskolernes Forening i Danmark. Højskolesangbogen indeholder stadig 84 sange og salmer af Grundtvig ud af i alt 572, et 
håndgribeligt udtryk for Grundtvigs fortsatte betydning for det folkelige og kulturelle liv i Danmark. I anledning af den nye udgave af Højskolesangbogen er Vartovbogen 2006-07 helliget højskolesangen med artikler af Birthe Dam Christensen ("Mit liv med højskolesangbogen"), Marie Høgh ("Højskolesang er åndens bindevæv"), Uffe Raahede ("Om at bringe stenene til at danse i takt"), Ole Brunsbjerg ("Den ny Højskolesangbog"), Karen Hanne Munk ("Sange fra vor store nabo"), Michael Bojesen ("Levende musik"), Jens Grøn ("Farvel og tak - velkommen og god vind"), Knud Damgaard Andersen ("Højskolesangbogen - en vej til folkelig dannelse?"), Peer E. Sørensen ("Nogle bemærkninger om konstruktionen af det danske landskab") og Jørgen Carlsen ("Synge vil vi”).

De to store oversættelsesprojekter til tysk og engelsk skrider planmæssigt frem. Det tyske projekt ved K. E. Bugge, Flemming Lundgreen-Nielsen og Theodor Jørgensen nærmer sig sin afslutning, og det første engelske bind, ved S. A. J. Bradley, er nu i trykken.

Også udredningsarbejdet vedrørende den udgivelse af Grundtvigs skrifter, der blev omtalt $\mathrm{i}$ sidste års årsberetning, skrider planmæssigt frem, og der er planlagt en række seminarer om udgivelsesarbejdet, som vil finde sted i løbet af 2007. Derefter vil der blive søgt om offentlig og privat støtte til projektet. Der er tale om et af de største danske udgivelsesprojekter nogensinde. I betragtning af Grundtvigs gennemgribende betydning for dansk kultur samtidig en af de betydeligste udgivelser, $\mathrm{i}$ folkelig bredde langt vigtigere end den udgivelse af Søren Kierkegaards skrifter, der netop af staten har fået bevilliget 11 millioner kr. om året i tre år til sin færdiggørelse. Det er projekter som udgivelsen af Kierkegaards og Grundtvigs, der viser, at Danmark er en fuldgyldig kulturnation.

Også i år skal der fra Grundtvig-Selskabets årsmøde lyde en tak til alle, der på forskellig vis har hjulpet selskabet $\mathrm{i}$ årets løb. Ansatte på Center for Grundtvigstudier ved Aarhus Universitet, på GrundtvigAkademiet, Grundtvig-Biblioteket og Vartov-Arkivet i København. Dertil kommer Kirkeligt Samfund repræsenteret ved formanden, Jens Bruun, og sekretariatsleder i Vartov, Hans Grishauge, sammen med sekretær Kirsten Grishauge. Forskningsrådet for Kultur og kommunikation skal takkes for støtte til udgivelsen af Grundtvig-Studier, og alle Grundtvig-Selskabets medlemmer i Danmark, Norge og resten af verden skal takkes for trofast støtte til og engageret medarbejde ved "studiet af N. F. S. Grundtvig, hans virke og hans stilling i åndslivet i og udenfor Danmark". 